Article

\title{
Qur'anic Interpretation and the Problem of Literalism: Ibn Rushd and the Enlightenment Project in the Islamic World
}

\section{Chryssi Sidiropoulou}

Department of Philosophy, Faculty of Arts and Sciences, Boğaziçi University, TB 350, Bebek 34342 , Istanbul, Turkey; E-Mail: sidiropu@boun.edu.tr; Tel.: +90-212-3595400 (ext. 7210);

Fax: $+90-212-2872469$

Academic Editor: Jonathan Hill

Received: 4 May 2015 / Accepted: 26 August 2015 / Published: 11 September 2015

\begin{abstract}
This article examines the claim that Ibn Rushd of Cordoba ("Averroës," 12th century B.C.) is a precursor of the Enlightenment and a source of inspiration for the emancipation of contemporary Islamic societies. The paper critically discusses the fascination that Ibn Rushd has exercised on several thinkers, from Ernest Renan to Salman Rushdie, and highlights the problem of literalism in Qur'anic interpretation. Based on Ibn Rushd's Decisive Treatise (Fasl al-maqāl), the paper investigates Ibn Rushd's proposed division of (Muslim) society into three distinct classes. The main question here is whether there is a substantial link between the people of the Muslim community, given the three distinct kinds of assent (tasdīq) introduced by Ibn Rushd. I argue that if such a link cannot be supplied, then it is hard to see in Ibn Rushd an enlightened social model for today's Muslim societies. Furthermore, that the great majority of people are prevented from having any contact with non-literal interpretation of the Scripture and non-revealed ways of thinking. The latter position, though, does not seem to bring Ibn Rushd close to the Enlightenment. My analysis of religious language is inspired by Wittgenstein's position that the meaning of a term cannot be detached from its use. I suggest that given the different lives of people belonging to Ibn Rushd's different classes, the terms they use can mean quite different things. This argument in fact weakens Ibn Rushd's association with the Enlightenment.
\end{abstract}

Keywords: Averroës; enlightenment; equivocation; Qur'anic interpretation; literalism; harmonization of philosophy and religion 


\section{Introduction: Ibn Rushd and the Enlightenment}

In approximately the last twenty years there has been an increased interest in the philosophy of Ibn Rushd of Cordoba ("Averroes," 12th century A.D.), as well as an effort to explore his position as a likely forerunner of the Enlightenment. Ibn Rushd's important position in the history of medieval philosophy, with particular emphasis on his role as commentator of Aristotle, had been well established. He had also been an important source of inspiration for many Arab intellectuals involved in the Nahda movement (during the late 19th and early 20th century.) With the organization of a large conference on Ibn Rushd and the Enlightenment in Cairo in December 1994 the question regarding whether he is a medieval precursor of the Enlightenment, but also whether he can be seen as a positive role model for the Islamic world today, was posed explicitly ([1], pp. 11-14). It is noteworthy that this renewed interest in Ibn Rushd surfaced at a time when Samuel Huntington had raised alarmist prospects of serious world conflict; the promulgation of Huntington's "Clash of Civilizations" thesis in 1993, motivated, as a reaction, an inclination to look for ways to bring cultures closer together and to form a basis of dialogue between the "West" and the Islamic world. Looking up to Averroes as an iconic figure for the cause of Islamic Enlightenment, has certainly had deep roots, as broadly acknowledged at both the Cairo conference already mentioned, and the one organized at Amherst, N.Y in 1996. After several centuries during which Ibn Rushd had all but been forgotten in the Islamic world, the 19th century heralded the emergence of reawakened in his philosophy by Arabic scholars and intellectuals. As the Arabic world came face to face with the fundamental questions and challenges of modernity, such as rationalism, emancipation from religious authority, secularism, heritage progress, and openness towards Western culture, an attempt to bring about an Arabic "awakening" or "renaissance," known in Arabic as Nahda (an-Nahdah) emerged. Primarily based in Egypt, but also in Beirut and Damascus, such scholars turned their attention to Ibn Rushd and put together perspectives for interpreting his work that fitted their own concerns and problematic. They sought in Ibn Rushd the root of an indigenous Arab perspective that would measure up to the challenges of a rational era.

To embark on a detailed presentation of this rich and fascinating intellectual production would be beyond the scope of this paper. Should one attempt such an exploration, Anke von Kügelgen's admirably lucid and comprehensive book Averroes \& die arabische Moderne. Ansätze zu einer Neubegründüng des Rationalismus im Islam ("Averroes and Arabic Modernity: Attempts at a New Foundation of Rationalism in Islam." (1994) is the obvious book to start from [2]. One can also benefit from Stefan Wild's article Islamic Enlightenment and the Paradox of Averroes (written in English), the first part of which constitutes a review of von Kügelgen's Averroes \& die arabische Moderne [3].

Both von Kügelgen ([2], p. 1) and Wild ([3], p. 380) make reference to Egyptian professor Mourad Wahba's formulation of what he, in 1979 had called "the Averroes Paradox." According to Wahba the Paradox of Averroes consists in the discrepancy between the influence that Ibn Rushd exercised in the West and that in the Islamic world. In Latin Europe, the Latin Averroists developed into an influential intellectual movement contributing to the emergence of a rationalist spirit which became formative of the European Renaissance and then, of the Enlightenment. Reversely, Ibn Rushd has had no following within his native Islamic civilization, where his influence remained quite limited. Characteristically, there has not been a "Rushdiyya" - an Arabic averroism, which, in Wild's words "would have corresponded to Latin Averroism" ([3], p. 389). 
First among those who attempt to revive the thought of Ibn Rushd has been Butrus al-Bustani (1819-1883), who published an article on Ibn Rushd in his encyclopedia Da' irat al-ma 'arif in 1876 ([2], pp. 61-62) and ([3], p. 381). In the second chapter of Averroes \& die arabische Moderne, Anke von Kügelgen embarks on an exploration of the Arabic reception of Ibn Rushd in the late 19th and the 20th centuries, starting with the "Rediscovery" (German: Wiederentdeckung) ([2], p. 61) of Ibn Rushd by Arab Christians ([2], pp. 61-65) and then continuing with the "salafiya" ([2], pp. 65-77). The great representatives of these two traditions are Farah Antun (1874-1922) and Muhammad 'Abduh (1849-1905), respectively. Characteristically, each provides a very different take on Ibn Rushd: in his Ibn Rushd wa Falsafatuh (Averroes and His Philosophy), Christian secularist Antun sees Ibn Rushd's rationalism as a precursor of secularism, a principle which Antun takes to be necessary for tolerance in that it separates the spiritual and the temporal, Antun takes to be necessary for tolerance ([4], p. 376). On his part, Muhammad 'Abduh, Grand Mufti of Egypt and an emblematic figure of the salafiya, saw in Ibn Rushd a great Islamic philosopher while he also rejected "the secularist thesis and reaffirmed the unity of the spiritual and the temporal in Islam" ([4], p. 376).

Von Kügelgen discusses various other prominent figures in the history of Ibn Rushd's reception in the Arab world ([2], pp. 180-323). All of the above explore questions typical within the Nahda intellectual milieu. Based on her book, Wild offers a concise enumeration of these scholars, together with their main theses. This list includes:

Muhammad 'Ammāra (b. 1931) and his plea for an "enlightened Islam;" Hasan Hanafi (b. 1936) and his construction of a modern Islamic culture; Tayyib Tizini (b. 1938) and his attempt to trace the roots of a materialist Islamic philosophical tradition; Muhammad 'Abid al-Jabiri (b. 1936) and his doctrine of an epistemological gulf between an "irrational" Mashriq and a "rational" Maghrib; Zaki Najib Mahmud (1905-1993) and his rationalist neo-positivism; and finally Muhammad 'Atif al-'Iraqi (b. 1935) and his call for a fresh start of Arabic philosophy as a critical and rational discourse, independent of revelation ([3], p. 381).

Another person worth mentioning is 'Adil Zu'aytir, translator of Ernest Renan's Averroes et l'Averroisme into Arabic. The translation was published in Cairo in 1957, bearing the title Ibn Rushd wa-l-Rushdiyya. Apart from the importance of the translation itself, it has also introduced the term "al Rushdiyya," which, as Wild remarks, provides an Arabic equivalent "Averroism" for the first time ([3], p. 388).

Instrumental to the formation of Ibn Rushd's association with the Enlightenment has been his Decisive Treatise (Fasl al-maqäl); its complete title being, Book of the Distinction of Discourse and the Establishment of the Relation of Religious Law and Philosophy [5]. It is written, as Thérèse-Anne Druart observes, in the form of a fatwa ([6], p. 101) with an avowed aim to pass judgment as to whether the study of Philosophy (hikma-wisdom) is allowed by the Law. This work offers an ingenious and thought-provoking analysis of the relationship between Islamic Scripture/Law (Shar) on the one hand, and Philosophy, on the other. Focusing on the Decisive Treatise is indispensable for exploring the averroist reaction to an issue that has always been very central in Islam: the place of literal and metaphorical interpretations of the Scripture, given the presence of ambiguous verses in the Qur'an. Ibn Rushd's response to this particular question is unequivocal: he contends that only 
philosophers with a sound knowledge of the "ancient sciences"-especially Aristotle - can interpret the ambiguous verses ([7], p. 39). This view not only conveys his philosophical commitments, but can also be seen as an implicit attempt to undermine the influence of the class of Islamic jurisprudents, namely, professional interpreters of Islamic law in Al-Andalus. In an unprecedented move Ibn Rushd makes philosophical reason formative of the text of the Scripture. He insists that philosophers should be the ultimate authority with regard to how the ambiguous verses of the Qur'an are to be read. In this way, even the premises on which the theologians themselves are based-should they derive from ambiguous verses-are to be determined by philosophers. Such clear distinction between natural (philosophical, demonstrative in its Aristotelian conception) reason and revelation of the Scripture, together with the prioritizing of the former, is in the heart of the connection between Ibn Rushd and the Enlightenment. Nevertheless, Ibn Rushd's reworking of the Aristotelian classification of arguments into (a) demonstrative; (b) dialectical; and (c) rhetorical, ushers in a division of the Muslim community into three classes of people, each of which is typically associated with one kind of argument. In her recent book Catarina Bello [7] remarks that "Three classes are listed according to type of assent, but they could also be considered political classes, since religion inevitably plays an essential role in Averroes' society" ([7], p. 38). Whether this division into three kinds of people corresponds to, or evokes, hardened social boundaries calls for further exploration. It is, nonetheless, a crucial point for the evaluation of Ibn Rushd's affinity with the Enlightenment as well as for the broader question of his significance as a model figure for Islamic societies and for intercultural dialogue in our times.

\section{2. "Averroës" as a Model-Literalism and Interpretation}

The monumental contribution of the dissemination of Aristotle's philosophy to the Medieval Western world earned Ibn Rushd the uncontested title of the Commentator. At the same time, his persistence in putting the Scripture to the test of rational evaluation has led many scholars outside of the Islamic world to view "Averroës" as an iconic opponent of religious authority, a kind of Muslim "anticlericalist". Part of the problem with this standpoint is the incomplete awareness that in Islam both the contrast between reason and religious authority and the opposition to religious officialdom involve quite different dynamics than they do in the Western world, where these oppositions originate. In effect, at times in the West, Ibn Rushd has been perceived as a case of irreligiosity. So writes Ernest Renan in his landmark 1852 book Averroès Et L'Averroisme: Essai Historique:

Ainsi, dans toute la philosophie scolastique, Averroès soutient un double personnage. D’un côté, c'est l' Averroès qui a fait le Commentaire, l' interprète par excellence du philosophe, respecté même de ceux qui le combattent; de l'autre, c'est l'Averroès du Campo Santo, le blasphémateur des religions, le père des incrédules. ([8], pp. 249-50). ${ }^{1}$

Today, we no longer see Ibn Rushd as "le précurseur de l'Antechrist," as Renan puts it ([8], p. 250). We do, however, allocate him an important historical role in bringing religion and its revealed

1 Translation from the French original: So in all scholastic philosophy Averroes maintains a double face. On the one hand, there is the Averroes who produced the Long Commentary, the interepreter of Aristotle par excellence, respected even by those who oppose him. On the other, there is the Averroes of Campo Santo, the blasphemous against religions, the father of the unbelievers. (Author's translation). 
ideas under the control of secular authority. Both in his celebrated Tahäfut-al Tahäfut, but notably more so in the Decisive Treatise (Fasl al-Maqāl), he clearly treats the relationship between philosophy and religion in a way that shifts the balance of power to the benefit of the former. In subjecting the Scripture to rational scrutiny, Ibn Rushd unleashed a tremendous potential for approaching religious texts independently of received authority. This significant dimension of his thinking has fitted nicely with the presumed need for social change in the Islamic world and the avoidance of a catastrophic "clash of civilizations". The publication of Averroës and the Enlightenment in 1996 by Mourad Wahba and Mona Abousenna addressed some of these questions by bringing together contributions of many international experts on the work and thought of Ibn Rushd. As one is to read on the back flap, the book sets itself the aim to explore whether Ibn Rushd "may be viewed as a medieval precursor of the European Enlightenment and as a rallying point for dialogue between East and West ([1], back flap)." Similarly, the then U.N. Secretary General Boutros Boutros Ghali is quoted saying, with reference to Ibn Rushd's commentary on Plato's Republic:

Indeed, there are pages of Ibn Rushd [Averroës] which speak to us all today, on the importance of the masses in politics, on the need to address their problems and their happiness. [...] These are moral imperatives as well as political necessities. Ibn Rushd, I know, would have understood. ([1], pp. 9-10).

There is also a relevant question by Mourad Wahba and Mona Abousenna, the editors of Averroës and the Enlightenment:

[...] we may ask whether the Enlightenment can become a factor by overcoming cultural stagnation and disintegration in the Arab-Islamic world. Can the philosophy of Ibn Rushd help to develop an appreciation for the Enlightenment in the Arab-Islamic world-and could this be a basis for establishing a bridge between Afro-Asian and European culture? ([1], back flap).

An important aspect of Ibn Rushd's thought is brought to light by British-Indian writer Salman Rushdie, another intellectual who follows suit in the public display of affection for Ibn Rushd. Rushdie, whose own family name was coined by his father in reverence for Ibn Rushd's memory, is seriously concerned with literalism. Essentially, he sees literalism in the interpretation of the Qur'an as a slippery slope on which fundamentalism and terrorism consistently feed. In the light of his own painful adventure with the fatwa asking for his execution, Rushdie sees in Ibn Rushd a powerful voice against what he describes as "the dead hand of literalism." For him, Ibn Rushd represents a noble cause that must be reinvigorated, a crucial ally against the "jihadists." In an interview with Nathan Gardels at the Huffington Post (10-7-2005), Salman Rushdie says:

Ibn Rushd and others in his time argued that language, too, is a human characteristic and therefore, it is improper - in Koranic terms - to argue that God speaks Arabic or any other language. That God would speak at all would mean he has a mouth and human form. So, according to Ibn Rushd, if God doesn't use human language, then the writing down of the Koran, as received in the human mind from the Angel Gabriel, is itself an act of interpretation. The original text is itself an act of interpretation. If that is so, then further interpretation of the Koran according to historical context, rather than literally, is quite legitimate. 
Ultimately, in the 12th century, this argument was defeated and needs to be raised again in the 21 st century.

[...] The dead hand of literalism is what is giving power to the conservatives and the radicals. If you want to take that away from them, you must start with the issue of interpretation and insist that all ideas, even sacred ones, must adapt to new realities [9].

Indeed, for Salman Rushdie, Ibn Rushd's ideals are not only universally valid and admirable, they also cut through class divisions. He argues in Le Monde: "Is it not time to raise the banner of Averroes (Ibn Rushd) and to carry it forward? Is it not time to say that, in our own era, his ideas suit everyone, the beggar as well as the prince?" ([9], third, non-numbered page).

An evaluation of the above claims requires a focus on two main factors: (a). Ibn Rushd's view concerning how the text of the Scripture is to be "read" and interpreted; and (b). his classification of arguments and theory regarding the three levels of assent in the truth of the Scripture. An analysis of both (a) and (b) can help disclose the role that Ibn Rushd allocates to (unaided) reason and, thus, render his high regard for philosophy more palpable. The Fasl al-Maqāl (Decisive Treatise) and also the Kitāb al-Kashf 'an al-manāhij al-adilla fi 'aqā'id al-milla (Explanation of the Sorts of Proofs in the Doctrines of Religion) are essential for such investigation.

Pivotal in the Decisive Treatise is Ibn Rushd's claim that the Scripture includes both obvious and ambiguous verses. ([5], pp. 51-54). The ambiguous ones call for interpretation, as they can be read in alternative ways. Boldly, Ibn Rushd makes use of the Qur'an itself, suggesting that the ambiguous verses should only be interpreted by those who have a capacity for demonstrative thinking. He puts forward an argument that aims to identify the latter with those described in the Qur'an as "confirmed in knowledge." The part of the Qur'an that Ibn Rushd has in mind is Surah Imran, verses 5-7:

It is He who sent down upon thee the Book,

wherein are verses clear that are the Essence

of the Book, and others ambiguous.

As for those in whose hearts is swerving, they follow the ambiguous part, desiring

dissension, and desiring its interpretation;

and none knows its interpretation, save only God.

And those firmly rooted in

knowledge say, 'We believe in it; all

is from our Lord'; yet none remembers, but men

possessed of minds. ([10], p. 73) (Author's emphasis).

The Qur'anic passage above introduces the idea that there are people "firmly rooted in knowledge" and "possessed of minds"- or of "sound instruction" and "understanding"-in M. Pickthall's translation - as opposed to others who are shaken by doubt ([11], p. 63). It also stipulates that the Scripture presents "clear" [Arabic: muhkamât] pronouncements, as opposed to verses that are “ambiguous" (Arberry) ([10], p. 73) or "allegorical” (Pickthall) ([11], p. 63). [Arabic: mutashabihât], with the former being the Scripture's very essence, its spinal cord. The crucial question then concerns what is to be done with the latter. Are the allegorical verses to be interpreted? If yes, by whom? This is 
a fundamental question. As the passage itself warns, people who feed on doubt desire the "interpretation" of the "ambiguous part" (Arberry) ([10], p. 73) or "seek to explain it" (Pickthall) ([11], p. 63). This is quite dangerous and may bring about the dreadful consequence of discord among Muslims. It is worth noticing that the problem of correct interpretation is considered to be not merely a theological or intellectual matter, but an issue that can potentially unleash tremendous social repercussions. In contrast to "those who doubt," people "firmly rooted in knowledge" declare their faith in the truth of the ambiguous verses but do not attempt to interpret them because they realize that nobody apart from God knows their interpretation. This is the idea one gets from Al-Imran, 7, in both Arberry's and Pickthall's translation. Ibn Rushd however, opts for a different punctuation in the original Arabic text, which leads to a radically different reading: he suggests placing the full stop after the phrase "And those firmly rooted in knowledge" ([5], pp. 53-54); [12], footnote 87, pp. 97-98).

Read this way, the Qur'anic passage suggests that nobody apart from God and those firmly rooted in knowledge knows the explanation of allegorical verses. On Ibn Rushd's alternative punctuation, the "men possessed of minds," who are "firmly rooted in knowledge," not only accept the truth and the divine origination of the ambiguous verses, but also understand their deeper meaning. The fact that Ibn Rushd puts forward a new interpretation of the Qur'anic passage above implies that this passage actually belongs to the category of the "ambiguous ones." In this respect, the concept of "knowledge" therein discovered is also subject to different interpretations. If interpreted in the first way just laid out, it suggests that only God knows what exactly the term "knowledge" means. If, however, it is interpreted according to Ibn Rushd's suggestion, then there is also a group of people who own the interpretation ( $t a^{\prime}$ will). These people understand the meaning of ambiguous verses and therefore, also of the term "knowledge." This knowledge is solid and has deep roots. Since they also understand the meaning of the term knowledge itself, their knowledge includes knowledge of knowledge itself.

Putting the matter in this way, greatly serves Ibn Rushd's ultimate purpose: to demonstrate that the knowledge mentioned in Al-Imran 5-7, is no other than philosophy. For what else is in a position to comprehend and offer a foundation to itself, apart from philosophy?

At this juncture it is worth examining what Ibn Rushd thinks in relation to philosophers, independently of his reading of Al-Imrân 5-7, while also taking his Aristotelianism into consideration. This brings us to an exploration of point $b$. as set above: in the context of his analysis of life after death Ibn Rushd puts forward a tripartite classification of people, according to their level of assent (tasdī $q$ ) to the truth of Scripture:

Thus people in relation to Scripture fall into three classes:

One class is those who are not people of interpretation at all: these are the rhetorical class. They are the overwhelming mass, for no man of sound intellect is exempted from this kind of assent. Another class is the people of dialectical interpretation: these are the dialecticians, either by nature alone or by nature and habit. Another class is the people of certain interpretation: these are the demonstrative class, by nature and training, i.e., in the art of philosophy. This interpretation ought not to be expressed to the dialectical class, let alone to the masses ([5], p. 65).

Ibn Rushd's distinction of people into three classes, can be traced back to Aristotle's classification of arguments in the beginning of the Topics into demonstrative, dialectical, contentious, and 
pseudoscientific ones, Aristotle also defines rhetorics as the art of persuasion in Rhetoric I, 1354a-b. According to this, rhetorical reasoning is exclusively aimed at persuasion ([13], p. 1325). ${ }^{2}$ Based on Aristotle's classification of arguments, Ibn Rushd limits their number to three: demonstrative, dialectical, and rhetorical ([5], p. 54). ${ }^{3}$.Moreover, in Ibn Rushd, the classification of arguments corresponds to a classification of people, on the basis of the type of argument each group characteristically uses. This can be seen as a vital move, the significance of which has to be been paid

2 According to Aristotle, reasoning is "demonstration," "when the premises from which the reasoning starts are true and primary, or are such that our knowledge of them has originally come through premises which are primary and true" (Topics, I, 100a 27-30). By contrast, reasoning is "dialectical" if it proceeds from opinions that are generally accepted. (Topics, I, 100a 30-31) See ([13], p. 188). Modes of persuasion are the constituents of the art of rhetoric. (See Rhetorics, I, 1354a 12-14). See ([13], p. 1325).

3 Ibn Rushd's division of arguments into three kinds derives from Aristotle (See [13]: Posterior Analytics I, 71b, Topics I, 100a, 101a20; Sophistical Refutations 164a-165b; Rhetorics I, 1354a.) The Arabs became familiar with the aristotelian categorization through introductions to the philosophy of Aristotle dating back to the late antiquity. Dimitri Gutas claims that a book-introduction to Aristotle's philosophy has been an important link between the late Aristotelianism of Alexandria and the philosophical school of Bagdat in its early days. According to Gutas, this book was written by Paul (Bûlus) the Persian, a Nestorian theologian and philosopher of the 6th century influenced by Alexandrian aristotelianism. Presumably written in Pehlevi, it was first translated into Syriac and then Arabic. Moreover, the Arabic translation of this work was included in the treatise concernig the nature and types of human happiness that was composed by Miskawaih (Tartīb as-sa' $\bar{a} d \bar{a} t$ ). In fact, it is identical to its second part, which presents a taxonomy of the parts of Aristotle's philosophy ([14], p. 232, 238-240, 244). The Arabic translation of Paul the Persian's text exercised considerable influence upon Al-Farabi and his classification of the sciences. In his analysis, Gutas maintains the existence of specific evidence pointing to Al-Fārābī's connection to the later stages of Alexandrian Aristotelianism. This connection went through the Nestorian Syrian tradition represented by Paul the Persian as well as, possibly, Abū BiŠr Mattā ([14], p. 255). Both Paul the Persian and Al-Fārābī in his Iḥ̣ā al- 'Ulūm (The Enumaration of the Sciences) differentiate between five kinds of syllogism: (a) Syllogisms that lead to certainty and are absolutely true. These are the subject matter of Aristotle's Prior and Posterior Analytics; (b) Syllogisms that lead to strong opinions and are more true than false. These are presented in Aristotle's Topics; (c) Syllogisms that are equally true and false and lead to persuasion, analyzed in Aristotle's Rhetorics; (d) Syllogisms that are more false than true and lead to error, examined in Aristotle's Sophistical Refutations); and finally; (e) Syllogisms that are totally false and give rise to imaginary impressions, explored in Aristotle's Poetics ([14], pp. 264-66). Ibn Rushd is familiar with this tradition and draws on it for his own classification of arguments. He thus reduces the initial five Aristotelian types of argument into three: (a) The demonstrative ones - corresponding to the first type of syllogism above; (b) The dialectical arguments - corresponding to the second and (c) the rhetorical arguments, which correspond to the third. On this basis, he then builds his division of the Muslim community into three classes of people, according to their specific ability to grasp truth in its purest form. Furthermore, Ibn Rushd associates his three-fold classification of arguments with the theological term tasdīq (assent), which signifies the acceptance of Islamic revelation on the believer's part and the subsequent assent to its stipulations. Here, Ibn Rushd's claim is that the assent given by each of the three classes is qualitatively distinct. The highest class accepts the truth of the revelation through demonstrative thinking. As Fakhry remarks "[Ibn Rushd] [...] proceeds to identify the demonstrative method with that of the philosophers, the dialectical with that of the theologians, and the rhetorical with that of the masses at large" ([4], p. 288). 
proper attention to. By dividing people according to their level of understanding, Ibn Rushd addresses the question of who can be entrusted with interpreting the Scripture. It is evident from the Fasl al-Maqāl that the difference between evident and ambiguous parts of the Qur'an should not be examined unless through consideration of the essential inequality that exists in people's cognitive capacities. Ibn Rushd maintains that what sets educated intellectuals apart from simple believers is the superiority of the former's level of assent (tasdīq) ([5], pp. 50-51). Further, he connects the issue of ambiguous verses to the classification of arguments. On this basis, he suggests that only demonstrative people should be allowed to interpret the ambiguous verses in the Qur'an. Most importantly, demonstrative understanding of the ambiguous verses sets the standard about how the Scripture is to be interpreted: were the apparent meaning of the Scripture to conflict with demonstrative conclusions, then it is not these conclusions that have to be rejected, but the Scripture itself has to be reinterpreted, this time allegorically. Hence the theologian/Islamic jurisprudent-"lawyer," emerges as a man of dialectical understanding. His level of assent is clearly second-rate, compared to that of the demonstrative thinker. In Fasl al-Maqāl II, 7, 20-25 he is essentially presented as a man of opinion, falling below the standard required for knowledge of God:

[...] We the Muslim community know definitely that demonstrative study does not lead to [conclusions] conflicting with what Scripture has given us; for truth does not oppose truth but accords with it and bears witness to it.

[...] For the lawyer has at his disposition only reasoning based on opinion, while he who would know [God] < has at his disposition $>$ reasoning based on certainty. So we affirm definitely that whenever the conclusion of a demonstration is in conflict with the apparent meaning of Scripture, that apparent meaning admits of allegorical meaning of Scripture, that apparent meaning admits of allegorical interpretation according to the rules for such interpretation in Arabic ([5], pp. 50-51).

A combination of the claim above with another one from II, 14, 5-10, leads to the conclusion that certainty derives from demonstrative syllogism:

And if he who would judge what is allowed and forbidden is required to combine in himself the qualifications for exercise of personal judgment, namely knowledge of the principles [of law] and knowledge of how to draw inferences from those principles by reasoning, how much more properly is he who would make judgments about things required to be qualified, i.e., to know the primary intellectual principles and the way to draw inferences from them! ([5], p. 58).

The difference between knowing the principles of the Scripture/the Law (both coming under the term shar in Arabic) and the knowledge of the primary principles of intellect is significant; it marks the distance between dialectical and demonstrative syllogism, respectively. What is important, as well as original, here is how Ibn Rushd views the class of Islamic jurists and theologians. The Islamic jurisprudent ( $f a q \bar{i} h$ ) is limited to the knowledge of the fundamental principles of Islamic revelation and Islamic law ([4], p. 120). Moreover, Islamic jurisprudence (fiqh) and theology (kalâm) are the two Islamic sciences whose adepts work with premises given in the Scripture. Their respective task is to draw the right conclusions from Scripural premises, and to defend them against attack ([4], p. 120). 
According to Ibn Rushd, this prevents the jurisprudent from interpreting the Scripture, for, given his inability to use demonstrative syllogism, he is not in a position to discern which parts of the Scripture are to be interpreted allegorically and how. By contrast, the person with the capacity for demonstrative syllogism sets the standard to which the apparent meanings have to comply. If the apparent meanings of the Scripture diverge from the conclusion of a demonstrative syllogism, then, it is precisely these meanings that have to be re-interpreted, this time allegorically. It is important here to emphasize the Aristotelian character of demonstration. For Aristotle, demonstration (“ $\alpha \dot{\alpha} \delta$ ó $\delta \varepsilon 1 \xi 1 \zeta$ ”), translated into Arabic as bürhan, constitutes the proper method of science. It aims not simply to produce the formally valid conclusion that a dialectical syllogism leads to, but also a conclusion that is true by sheer fact of its having been drawn from true premises. This is why, according to Ibn Rushd, the demonstrative person is one who knows the "primary principles of intellection." Only with proper knowledge of the principles can one make sure that one's premises are true- so that he can then extract a demonstratively true conclusion. By contrast, the jurisprudent or the theologian is a person who has no control over the premises of his arguments, given that these are authoritative pronouncements offered in the Scripture. This is the sense of his dialectical status and his inability to adjudicate which Qur'anic verses are to be interpreted allegorically and which not.

Allegorical interpretation can harm the most intellectually vulnerable members of the society, namely, "rhetorical" class. There ensues a powerful objection to making allegorical interpretations public, an error of which Abū Hāmid [Al-Ghazālī] is particularly guilty, according to Ibn Rushd. Indeed Ibn Rushd summarizes his position vis-à-vis the masses as follows:

When something of these allegorical interpretations is expressed to anyone unfit to receive them-especially demonstrative interpretations because of their remoteness from common knowledge - both he who expresses it and he to whom it is expressed are led into unbelief. The reason for that [in the case of the latter] is that allegorical interpretation comprises two things, rejection of the apparent meaning and affirmation of the allegorical one; so that if the apparent meaning is rejected in the mind of someone who can only grasp apparent meanings, without the allegorical meaning being affirmed in his mind, the result is unbelief, if it [the text in question] concerns the principles of religion.

Allegorical interpretations, then, ought not to be expressed to the masses nor set down in rhetorical or dialectical books, i.e., books containing arguments of these two sorts, as was done by Abu Hamid. They should $<$ not $>$ be expressed to this class; [...] ([5], p. 66).

It would be helpful to explore the notion of allegorical interpretation - along with Ibn Rushd's claim that it should not be revealed to those incapable of demonstrative thinking - by focusing on a specific, as well as central, case, such as the case of belief in the Hereafter and in the Judgment Day. The Qur'anic proclamation of God as "Owner of the Day of Judgment" in the very beginning of the Scripture (Surah 1, Al-Fatihah) testifies to the tremendous significance that the Judgment Day has for Muslims ([11], p. 31). ${ }^{4}$ From Ibn Rushd's standpoint, this is an issue that is both fundamental for faith

\footnotetext{
4 This becomes very clear right from the first surah of the Qur'an, the Al-Fâtihah. It reads as follows:
}

THE OPENING

Revealed at Mecca 
and very complex to interpret. He urges us to acknowledge that different people approach the question of life after death from different angles according to their natural capacities. In the following excerpt from the Kitāb al-Kashf he goes over the main point:

The truth in this question is that every man's duty is [to believe] whatever his study of it leads him to [conclude], provided that it is not such a study as would cause him to reject the principle altogether, by denying the existence [of the future life] altogether; for this manner of belief obliges us to call its holder an unbeliever, because the existence of this [future] state for man is made known to people through their Scriptures and their intellects ([5], p. 77).

In the excerpt above it becomes evident that there is a principle indispensible for all people, namely, that an afterlife exists. To say that human life ends with the physical demise of man constitutes unbelief ( $k u f r$ ). Interestingly, Ibn Rushd does not add anything about judgment for one's good and evil acts on the Day of Doom.

In addition to this fundamental principle, however, there is reference to people's distinct levels of understanding. The limits between them should not be crossed. Ibn Rushd adds in the Kitäb al-kashf: "For this reason we find the people of Islam divided into three sects with regard to the understanding of the symbolization which is used in [the texts of] our religion referring to the states of the future life" ([5], p. 76).

On the next page, describing literal and metaphorical interpretations of the afterlife, Ibn Rushd mentions a claim reportedly made by Ibn 'Abbas, to the effect that "There is nothing in this lower world like the next world except the names." Then he makes the following striking comment:

It seems that this opinion is more suitable for the élite; for the admissibility of this opinion is founded on facts that are not discussed in front of everyone. One is that the soul is immortal. The second is that the return of the soul to other bodies does not involve the same absurdity as $<$ its $>$ return $<$ to $>$ those same [earthly] bodies. ([5], p. 77).

Without explicitly committing himself to any of these views, Ibn Rushd advises that ideas like those of Ibn 'Abbas, disavowing literal continuation of a person's existence after death, be kept secret from the masses. Simple believers should follow the Qur'anic way of talking about the issue strictly literally. In his view, Islamic faith is not protected by philosophical arguments aimed at strengthening believers' faith; on the contrary, rationalist renderings of the Qur'anic language and imagery have nothing to offer to simple believers; on the contrary, in overwhelming them with matters they cannot face up to,

In the name of Allah, the Beneficent, the Merciful.

1. Praise be to Allah, Lord of the Worlds,

2. The Beneficent, the Merciful.

3. Owner of the Day of Judgment,

4. Thee (alone) we worship; Thee (alone) we ask for help.

5. Show us the straight path,

6. The path of those whom Thou hast favoured;

7. Not (the path) of those who earn Thine anger nor of those who go astray.

See ([11], p. 31). (Author's emphasis). 
they sow the seeds of doubt and unbelief in their minds. Were one to indulge in it, one would be doing a major disservice to the cause of Islam. In Ibn Rushd's eyes, an example of the latter case had been Abu Hāmid [Al-Ghazālī], but this is an issue beyond the present confines of this paper. An unlearned person may be made to feel that these matters are so controversial and complicated that the truth cannot be easily found. If truth appears so elusive, this simple person may even believe that there is no truth in this matter at all. Given this, the "material" and anthropomorphic depiction of the afterlife in the Qur'an is the best medium for imparting the truth about afterlife to the masses. In the Kitäb al-Kashf Ibn Rushd even adds that the presence of such anthropomorphic language, full of sensory images, is a mark of Islam's superiority over other religions:

All religions, as we have said, agree on the fact that souls experience states of happiness or misery after death, but they disagree in the manner of symbolizing these states and explaining their existence to men. And it seems that the [kind of] symbolization which is found in this religion of ours is the most perfect means of explanation to the majority of men, and provides the greatest stimulus to their souls to [pursue the goals of] the life beyond; and the primary concern of religions is with the majority ([5], p. 77).

For Ibn Rushd the Qur'an's metaphorical sensory language makes it superior to the Christian Scripture; as he sees it, the latter's use of highly spiritual language expresses an indifference to the needs of the common man. Otherwise, the Qur'an does not convey a message that is essentially different from the other two monotheistic religions. It is in the way it conveys the same revealed truth that Islam is superior. In fact, the masses must believe that human existence does not end with physical death. As Majid Fakhry notes, for Ibn Rushd survival after death ( $\mathrm{ma}$ ' $\hat{a} d)$ is no matter of disagreement between religious laws (sharâ' $i^{6}$ ) and philosophical demonstrations. Their difference is about the mode of survival, not whether there will be survival or not ([15], p. 23).

A demonstrative philosopher understands that the human soul cannot separate itself from the body and reunite with it at a later time. This is an idea totally incompatible with the Aristotelian framework of assumptions concerning the soul, to which Ibn Rushd is committed. Even if the confines of the present work allow for only a very brief look into the Aristotelian conception of the soul, it would be helpful to introduce its main parameters.

There has been a complication for scholarship, however, having to do with the nature and function of the so-called active intellect brought up in Aristotle's De Anima, 430a10 ([13], pp. 591-92). Given that the active intellect does not depend on any bodily organ, what about its continued existence after the demise of one's physical body? Furthermore, if the active intellect is eternal and immortal, does this render human survival and life after death possible?

On his part, Ibn Rushd, analyzes the question of the intellect in Aristotle in his three Commentaries on the "De Anima," Short, Middle and Long, but also in five other works ([16], p. 199, footnote 26). Assuming that his most complete and final position concerning the intellect is to be found in the Long Commentary ([16], p. 192), Ibn Rushd claims that after death, each individual person's material intellect is absorbed into a single universal material intellect for all mankind.

Aristotelian interpretation apart, Ibn Rushd is also a Muslim. In this capacity, he is then faced with an intractable problem: the existence of single material intellect within which all individual human intellects merge, seems to be at a considerable distance from the Qur'anic eschatology concerning the 
Hereafter. This is a very serious issue, especially because in Islam denying the afterlife is a mark of unbelief. ${ }^{5}$ The thesis that there is one unified intellect for all mankind had become very controversial in thirteenth century Western Europe where it was propounded by the Latin Averroists, the Western philosophical followers of the Commentator. Significantly, it became notorious and was strongly attacked, among others, by Thomas Aquinas in his De Unitate Intellectus contra Averroistas ([15], pp. 151-56; [18], p. 25).

\section{But Do They Believe the Same Thing? Equivocation in Language and Unity in Diversity}

Ibn Rushd's Aristotelian outlook raises a serious problem for him, the severity of which threatens to vitiate his whole account of the afterlife: there has hardly been anybody — apart from himself and his secular followers, such as Siger of Brabant - that accepted the Averroist thesis concerning the unicity of the intellect as compatible with monotheistic belief. An important matter here is what, in contemporary terms, is termed "the problem of personal identity/continuity." In other words, what is it that makes me the same person through the passing of time? Monotheistic religions tend to view the human soul as the bearer of personal identity, the real essential person. The eschatological promise of eternal life opens to us on the basis of our unique soul.

Personal identity is a very intricate question and there is a lot to discuss as to whether it is meaningful to extend the concept of personal identity/continuity so that it involves life after death, or not. For the present purposes, though, this is almost beside the point. The issue here is not whether Ibn Rushd's theory of the active intellect as a unified cosmic intellect is, per se, acceptable or not; rather, it is to investigate whether it offers an account of the afterlife which is even approximately the same as the one that the dialectical and rhetorical class get from the Qur'an uninterpreted allegorically.

It seems quite hard to consider them the same, mainly because the literal Qur'anic account of the afterlife offers an eschatological promise for each and every individual Muslim. Ibn Rushd's philosophical account (merging of all souls into a unitary cosmic intellect) seems to leave no room at all for survival of individual persons after death. This point bypasses the issue of corporeal versus spiritual afterlife, for Ibn Rushd's demonstrative account excludes not only a bodily afterlife but also an afterlife envisaging an immaterial, but personal, soul.

The Qur'anic account emphasizes in the strongest possible terms the Day of Judgment. The Day of Judgment constitutes the most fundamental point of Islamic faith, almost on the same level with accepting that there is no God but God and that Muhammad is his prophet ([11], p. 31). By contrast, the demonstrative account seems to exclude this possibility too, not only because Ibn Rushd seems to be curiously silent about it, but also because Judgment after death presupposes some kind of continuity of personal existence as well as individual responsibility for individual deeds.

Seen from the perspective of a Muslim (but also of a Jew or Christian) a religious way of life fundamentally involves an eschatological standpoint and anticipation of a final Day of Judgment. This is very different from one where no personal life after death is expected. Different priorities are followed, different ways of looking at things, a different sense of what is valuable, and what not, a different understanding of time. Moreover, there can be fundamental differences in action and also in

$5 \quad$ See Book III from ([17], pp. 324-35). 
the way in which a person places himself or herself within society. Such differences may go as far as preventing a Muslim who believes in a literal(ist) afterlife and a demonstrative Aristotelian philosopher from holding a shared view of the matter. In the light of this the claim that they believe the same thing expressed differently appears shaky.

Perhaps the following way could be envisaged: as a person of demonstration, Ibn Rushd could say that he does not expect personal survival after death, or a Day of Judgment. He resigns himself to accepting the relevant Qur'anic declarations while remaining agnostic about the mode of the afterlife; in other words, without knowing how it will come to be. Such a move, however, is closed to Ibn Rushd; for this is the notorious bila kayf (= not knowing how) position advocated by the literalist school of jurisprudence associated with Ibn Hanbal and his followers. Accepting personal immortality bila kayf would be a move within a strictly literalist frame of explanation that cannot satisfy the standards of a "demonstrative" scholar. Only such a move, though, could bring the demonstrative thinker closer to the "rhetorical" common man.

Ultimately, Ibn Rushd presumes that the important and relevant similarity between the "demonstrative" and the "rhetorical" people's understanding of immortality concerns the that, rather than the how. Nevertheless, on the how of immortality, whether it will be literally personal or demonstratively impersonal two quite different ways of life will come to be based. These ways of life are definitely formative of what exactly is meant by "life after death," the "Hereafter" and "Judgment Day" when these words and their corresponding concepts are used inside their framework.

Ibn Rushd clearly warns against disclosing to the common people the demonstrative truth about the afterlife. Both Oliver Leaman and Charles Buttersworth argue against considering this as hypocritical on his part. They both argue - and rightly so - that Ibn Rushd was mostly interested in cultivating shared values in society, a minimum of moral consensus, as we may say today ([19], pp. 179-96; [20], pp. 6-18). This may well be the case, and, if it is, Ibn Rushd is not highly original about this. It is interesting to notice that, unlike Leaman, Buttersworth integrates this element into his view of Averroes as a defender of religion. This is not the focus of the present examination, though. Even if we accept that Ibn Rushd was not an advocate of "double truth" ([21], p. 171), ${ }^{6}$ it can still be argued that his classification of people into three fixed and insulated groups eventually results into an objectionable duality in society and may even fail to uphold the moral consensus he so ardently sought. Consequently, that this is neither a very enlightened point of view nor quite promising as a source of inspiration for many socially tormented Muslim countries today.

In order to clarify what we mean by "duality in society" let us return to the case of the afterlife. Time and again, the hope of life after death has been considered a means of providing comfort from the vicissitudes of life. On this basis it has been charged with promoting a level of complacency about

6 See ([21], p. 171). Leaman describes the doctrine of double truth as follows: As we know, this principle became highly controversial in Christian and Jewish Europe when it was generalized into what came to be known as the "doctrine of double truth." According to this doctrine, a proposition could be both true philosophically and true theologically, even though the philosophical understanding of it is contrary to the theological one. This is sometimes seen as far too radical a notion to be identified with ibn Rushd, but I have come to think that this is probably wrong. Certainly no proposition could be both true and false at the same time, but it is clearly possible for a proposition to be true when taken in one way, and false when taken in another. This is surely what the doctrine of double truth came to mean in medieval Europe, and this also explains how radical it is. 
social ills, transferring redemption out of space and time. Whatever one may think about the existence of an afterlife, it would be hard to deny that belief in it is formative of powerful attitudes and ways of acting. One may, for example, try to "take life in one's own hands" and allot no hope about one's future to factors beyond what is tangible. Others may have an out of the ordinary view of the world as a theater of divine action and eschatology. This could strengthen the inclination to take things as they come, without much resistance and effort to take control of things. Which one of the two attitudes is praiseworthy and to be sought is not relevant at this point. The relevant question is whether they are different or not. It is certainly plausible to answer this question in the affirmative. Furthermore, it is reasonable to assume that a difference in individual mindset like the one above gets greatly amplified within a social context.

It is significant that such contrasting personal attitudes, which help shape antithetical social realities, are embedded in what Ibn Rushd sees as different expressions of the same belief in the truth of the afterlife. The problem, though, is that what is to count as expression of the "same" belief cannot be unconnected to concrete attitudes, ways of acting, and aspects of living one's life. Thus a literalist understanding of the future life, or of divine agency, or even of God's knowledge of particulars and providential action shape the possibility of a certain way of life. Ibn Rushd's "demonstrative" reading of these issues raises the possibility of very different responses to the challenges of human life than those of the average believer. In this way a clear sense of divergent ways of life emerge.

In connection to the above, Oliver Leaman suggests that there is an unsympathetic view of Averroes, which should be resisted. In his analysis of Ibn Rushd's philosophical methodology, he emphasizes the great weight that the latter places "on the notion of equivocation and ambiguity in our language" ([19], p. 193). In Leaman's view, this holds the key to understanding Ibn Rushd's theory of different paths to the truth and can rebut charges of "complacent elitism" and, more generally, of being disingenuous. He describes the "unsympathetic view" of Averroes as follows:

The falāsifa seem to place the less sophisticated members of the community in the role of children who need not and cannot be told the whole truth because it would weaken their acceptance of adult rules, children who need to be put in their place by stories of bogey men and fairies and so on. This unsympathetic view of Averroes should be resisted. ([19], p. 192).

In order to rebut this view, Leaman revisits Ibn Rushd's example of a medical doctor treating patients in the Fasl al-Maqāl. According to the latter, a good physician has to promote his patients' health by making sure that they get the most effective treatment and follow a lifestyle most conducive to health, but he is not out to disseminate medical knowledge that they cannot digest. This would be like inviting them to debate the reasonableness and the whole point of seeking medical treatment or advice. Leaman quotes the following lines from Fasl al- Maqāl 23:

[...] this comparison is certain...it presents a true analogy, in that the relation of the doctor to the health of bodies is [the same as] the relation of the legislator to the health of souls: i.e., the doctor is he who seeks to preserve the health of bodies when it exists and to restore it when it is lost, while the legislator is he who desires this [end] for the health of the souls (FM 23). ([19], p. 193). 
The legislator mentioned in the above quotation is God. Indeed, the phrase following immediately after is "This health is what is called 'fear of God'." ([5], p. 67). In his analysis, Oliver Leaman, focuses on the fact that the legislator has as his mission to preserve and restore the health of souls. This is a feature that, according to Leaman, has to characterize the man of demonstration as well. This is because he is in some sense also a kind of legislator who interprets the Law given by God and has the social responsibility to ensure the ethical health and the well-being of the community. In his social mission, the man of demonstration must communicate to the simpler people what he knows to be true through seeking ways of persuasion. Correspondingly, Leaman writes: "He [Ibn Rushd] knows why people should act in a certain way, and he knows this through demonstrative reasoning. He uses his skill as a communicator to persuade the majority of the community to act accordingly" ([19], p. 193). Most importantly, according to Leaman, "The point about the stories which are widely broadcast in the community is that they must be true" ([19], p. 192). The man of demonstration does not use his persuasive skills in the way a manipulator would do. As Leaman puts it, in trying to persuade the people, "what he [the philosophical legislator] urges them to do must be based on something which is true" ([19], p. 193).

Without doubting this picture of a "sincere" Averroes, that Leaman supports, one could critically dwell on two elements discernible there. The first is the idea that the philosopher, as a man of demonstration and at the same time a legislator, has to ensure consensus in the community. Connected to this is the question of unity and plurality with respect to what words mean. As Leaman observes, Ibn Rushd "argues that equivocation is an inevitable aspect of our language, since that language has to describe a wide gamut of views using the same name" ([19], p. 195). On the same page, Leaman continues with the uncontroversial claim that "We must respect the different uses of the same word because they represent different points of view, different points of view of the same thing" ([19], p. 195).

Ibn Rushd would certainly agree with the above lines for he definitely believes that one word may be used in a variety of ways. Leaman represents his position correctly. Nevertheless, the issue of ambiguity in Ibn Rushd is very complex and has been examined in connection with Ibn Rushd's Aristotelian roots. Moreover, Leaman offers an analysis that sees ambiguity as part of Ibn Rushd's philosophical methodology, as notably manifest in his response to Al-Ghazālī's attack. In the Categories Aristotle had distinguished between homonymy, synonymy, and paronymy. (Cat. 1a.1) Two things are said to be homonymous when they share the same name but different definitions of their essence (ousia), and synonymous when they share both the name and the definition of their essence. Thus a man and his picture are hononymously an animal, whereas a man and an ox are synonymously so. In the former case, what makes a man an animal (a living being) is different from what makes his picture an animal. In the latter case, by contrast, a man and an ox are both animals, namely, they are both living beings. Finally, two things are paronymous when the name of the one derives from the name of the other, albeit in a different grammatical form: for example the word "grammarian" derives from the word "grammar" and is paronymous with it. In Richard McKeon's edition of The Basic Works of Aristotle, translator E. M. Edghill renders the term "homonymous" as "equivocally" the term "synonymous" as "univocally" and the term "paronymous" as "derivatively" ([13], p. 7). It has to be stressed that in Aristotle's account, it is things, not worlds that are homonymous, synonymous or paronymous, it is things that are said to be named equivocally, univocally or derivatively. Apart from 
the Categories, Metaphysics $\Gamma 2,1003 \mathrm{a} 33-1003 \mathrm{~b} 7$ is also important, as it succinctly expresses what in contemporary philosophy is called "focal meaning." Discussing the various meanings of the term "healthy," Aristotle states:

There are many senses in which a thing may be said to "be," but all that "is" is related to one central point (pros hèn), one definite kind of thing, and is not said to "be" by a mere ambiguity. [N.B.: (ouch homonymōs, not "homonymously." (Author's italics)].

Everything which is healthy is related to health, one thing in the sense that it preserves health, another in the sense that it produces it, another in the sense that it is a symptom of health, another because it is capable of it. And that which is medical is relative to the medical art, one thing being called medical because it possesses it, another because it is naturally adapted to it, another because it is a function of the medical art. And we shall find other words used similarly to these. So, too, there are many senses in which a thing is said to be, but all refer to one starting point; [...] ([13], p. 732).

Ibn Rushd's position on univocity, equivocation, and ambiguity is to be understood in reference to his Middle Commentary on Aristotle's Categories (Talkhīs kitāb al-maqūlāt), his Long Commentary on the Metaphysics (Tafsìr Mā ba'd al-tabī'ah, and various parts of the Tahäfut al-tahäfut. In the last chapter of his book Averroes and his Philosophy, Oliver Leaman offers an analysis of ambiguity in Ibn Rushd. In his view, Ibn Rushd rejects Ghazalian univocity about divine predicates. Moreover, Ibn Rushd takes his objection beyond the context of the dispute with Al-Ghazālī, insofar as he insists in the Long Commentary on the Metaphysics that the language we use to refer both to God and to things in the world is neither univocal nor equivocal, but analogical. ([19], p. 185). In this language there is a relationship of priority and posteriority, while the application of words to God is primary. Leaman refers to H. Wofson's account in "The Amphibolous Terms in Aristotle, Arabic Philosophy and Maimonides," contending that "Wolfson argues convincingly that in many of the contexts in which Averroes uses the notion of equivocation he is really referring to analogy or ambiguity" ([19], p. 185).

In his account, Leaman focuses on Ibn Rushd's prioritization of the "pros hēn equivocals," that is to say, of terms in language that do not only share their name but also display similarity in the objects. Such a similarity forms the basis to the sharing of the name ([19], p. 183) ("pros hēn" equivocals are what Aristotle discusses in the quotation from Met. 1003 a 32-1003b7, stressing that they are not related on the basis of "a mere ambiguity"). The importance that Ibn Rushd attached to pros hēn equivocals enables him, according to Leaman, to view the categories in terms of priority and posteriority. Leaman considers this outlook ([19], p. 184) to be an erroneous interpretation of Aristotle on Ibn Rushd's part, but at the same time a significant aspect of his theory of meaning. Having presented the example of fire predicated per prius at posterius (Tahäfut, (370-1), he then quotes the following also from the Tahäfut, (387)):

there are things which have a term in common not univocally nor equivocally, but by the universality of terms analogically related to one thing, and that the characteristic of these things is that they lead upwards to a first term in this genus which is the first cause of everything to which this word refers, like warmth, which is predicated of fire and all other 
warm things (TT 387) ([19], p. 186) This example relates to Aristotle's account of focal meaning, namely the position that an expression has a primary sense by reference to which its other senses can be explained.

The term "warm" paradigmatically and in its fullest sense refers to fire. Nevertheless, it can also be used in the case of, for example, a hot bottle. This, though not univocal, would still be a use congruous to the way warmth is predicated of fire. Another example from the Long Commentary on the Physics also cited by Leaman ([19], p. 188) has to do with the meaning of the term "man" when predicated of ordinary people and of philosophers (where a philosopher is "one perfected by theoretical knowledge.") The use of the term "man" is equivocal between these two applications. In the light of the above, the application of the term "man" to (a) a person perfected by theoretical knowledge; (b) to someone not perfected by it, and (c) to someone not even able to be perfected by it, is equivocal, in as much as the term "man" can be applied to a living person as to a human corpse, and to a rational being as to a stone.

Unfortunately for Ibn Rushd, however, this methodological understanding of ambiguity cannot be the end of the matter as regards whether different people mean the same thing or not. For similarity and difference are always defined by reference to a certain context, and things are similar or different according to a certain criterion or set of criteria. According to what criterion, for example, does Ibn Rushd's demonstrative understanding of immortality constitute an understanding of the same thing as the common man's understanding of bodily, individual survival? It may be the case that the demonstrative and the common person put the Qur'anic sensory images to very different use in their lives; that such different uses constitute different meanings and give rise to unrelated attitudes and ways of acting, as we tried to show earlier in this chapter.

Leaman makes things even harder by attributing to Ibn Rushd the thesis that "It is an error to represent some uses as essentially more accurate than others" ([19], p. 195). To start with, it is very difficult to see how an Aristotelian such as Ibn Rushd would adopt a view of language that is at variance with an essentialist picture of the world. One of Aristotle's devices for semantically unifying the application of a word in various instances is the so-called non-chance homonymy, what scholars nowadays call focal meaning. The focal application of the word is the one that underpins all others. ${ }^{7}$ This undeniably implies that some uses of the word are essentially more accurate than others.

Let us further explore the two issues in their interconnection. As a man of demonstration, Ibn Rushd may talk about the future life and use the same words of the Qur'an that a simple believer also uses. In his mind these words do not conjure up vivid anthropomorphic pictures of a sensuous paradise or indeed of a burning hell. In the common person's mind, however, the "afterlife" is connected with exactly this kind of images. Still, the demonstrative philosopher may feel the presence of God in his life and also seriously contemplate the question of ultimate human destiny and the afterlife. As Ibn Rushd presents it, they both have the same starting point, namely the Qur'anic assertion of an afterlife for human beings. However, what "Hereafter" means is equivocal between the different uses into which it is put in different contexts.

As an Aristotelian, Ibn Rushd should be aware of the fact that the equivocal use of a word in its different applications is not simply a linguistic phenomenon but embedded in ontological differences.

7 For an introduction to focal meaning and ambiguity in Aristotle see [22]. 
This entails that an Aristotelian cannot easily, if at all, talk about the same reality by using a single word equivocally - either the realities picked up by the two equivocal applications of the term are not the same but related to some extent, or the term is not used equivocally in its two applications, but univocally. The important question to ask is to what extent the realities picked up in equivocal applications of a term are connected or not.

In the case we are considering, it seems quite reasonable to say, along with Oliver Leaman, that the word "afterlife" is being equivocal in its two applications - the "demonstrative" and the "rhetorical." Unlike Leaman, though, we shall claim that the sense of "same" reality involved is very shaky. Indeed so precarious that renders Ibn Rushd's theory of different levels of assent to the truth of the Qur'an (=the "same" religious truth) highly problematic.

If I am a "rhetorical" person I believe — on the basis of literal understanding of the Qur'an — that God knows every particular thing and event, every leaf falling from any tree. He knows me and everything about me. Not only do I believe that he is omniscient and omnipresent but also closer to me than "my jugular vein" ([11], p. 370). ${ }^{8}$ I also believe that my life not only does not end when I die, but that another life, awaits me, the individual person I am, a life in which I may even get united with my loved ones who departed before me. In what I believe thoughts of reward and retribution are most important. My ways of looking at the world, as well as at human life and relations, are permeated by this spirit. I do not doubt the value of petitionary prayer or the importance of the specific rituals of my own religious tradition. In fact, I tend to believe that what I can do without the guidance and the help of God is quite limited. I turn to him for help in coping with illness or poverty.

If I am a philosopher like Ibn Rushd and I demonstratively know a very different "truth" concerning the mode of divine action, I believe in a rather "detached" God. I do not expect him to improve my particular conditions of life, and I most probably do not see the wretchedness of present life as a divine punishment or even a divine pedagogy. Furthermore, I do not expect an extension of my (personal) existence after death to offer me redemption from my present misery. If God, as Avicenna had claimed, does not know particulars, or if we are not in a position to know the specific mode of God's knowledge, as Ibn Rushd himself claims in his Tahäfut al-Tahāfut does it make sense to seek his help in times of sickness, war, poverty, disaster ([15], p. 21)?

Let us also remember that these are not academic issues. Illness constitutes perhaps what an individual is most afraid of in his or her life; poverty still bedevils a huge part of the population in many parts of the world, numerous Islamic countries included. "Demonstrative" and "rhetorical" people respond to these realities in different ways, as was argued above. On the basis of such different responses, different lives develop. In their turn, the latter give rise to different social realities, but then the "demonstrative" person's application of the term "afterlife" leads to very different societal effects than the "rhetorical" person's application. In the light of this, it is difficult to see how the two applications do not differ in priority, given that the demonstrative one is the application of the lawgiver and also represents the perspective of people to whom Ibn Rushd attributes complete happiness (the demonstrative philosophers).

8 See ([11], p. 370). Surah Qâf: 16. We verily created a man and We know what his soul whispereth to him, and We are nearer to him than his jugular vein. 
This now brings us back to Leaman's claim that no perspective has or should have priority over another one. A general philosophical analysis of this claim is certainly beyond the scope of the present discussion. Nevertheless, whether such a position can rightly be attributed to Ibn Rushd is a different issue whose examination is being called for.

\section{The Limits of Equivocation. Is Ibn Rushd Successful in Keeping Society Together?}

The averroist classification of people into three "classes," on the basis of their respective capacities for using arguments, confers upon each of these social groups a permanent position and status. The level of assent for each one of them is given once and for all-for Ibn Rushd considers it part of their essential identity. The "rhetorical" level, for example, is seen as complete and sufficient as it is. "Rhetorical" people do not have to strive to fulfill any potential for ascent to the next level. Not only do they not have to try, they do not seem to be encouraged to do so, either. The dialectical theologians should neither communicate difficult issues of interpretation to the lower class nor try to substitute the demonstrative class in interpreting the ambiguous verses of the Scripture. They are not in a position to compete with the philosophers in adducing the first premises for syllogisms leading to the truth. As for the demonstrative class, its members are not to use dialectical or, even worse, rhetorical arguments. Being endowed with demonstrative ability, they can see into the two lower perspectives and recognize them as exactly this: as limited perspectives on the "same" thing. On their part, the dialectical and the rhetorical class do not seem to have an awareness of their own perspective as limited. It is the demonstrative understanding of things that offers the constitutive framework of the classification. Being the rational point of view, it can recognize and evaluate the other two - the reverse is not the case. Ibn Rushd thinks of demonstrative reasoning in a way quite reminiscent of that in which Plato conceives the rational part of the soul in his tripartite division of the soul in the Republic. The same holds for the demonstrative class. They are similar to Plato's Guardians. In their being predominantly rational, the Guardians think of the community as an organic unity. Their perspective coincides with that of the city as a whole, unlike the perspectives of the Auxiliaries and Producers, which remain fragmented and partial. In a parallel way, Ibn Rushd's people of demonstration represent the rational and universal understanding of reality, whereas the dialectical and rhetorical people remain trapped in incomplete understanding, at best, being unable to transcend the limitations of their specific condition. If this is so, then it is very hard to accept that the claim "no way of expression should have priority over the others" can possibly be Ibn Rushd's own.

A further point we would like to explore concerns the validity and suitability of the parallel between the legislator in the specific sense of demonstrative thinker and leader of the community on the one hand, and the medical doctor on the other. Ibn Rushd takes the two cases to be parallel, in reviving an ancient Greek parallelism between physical health and justice as health of the soul and of the city.

Ibn Rushd's parallelism brackets together a professional expert (physician) and a person who is described not simply as a rational thinker and demonstrative interpreter of the truth of Islam, but who also has the task, responsibility, and authority to decide what is best for everybody in the community to believe. In the light of Ibn Rushd's medical metaphor, politics appears more as a game of expertise rather than a matter of social consensus. The parallel strengthens the view that Ibn Rushd does not give to all forms of expression equal priority. Moreover, it draws attention to an implicit, but clearly 
authoritarian, potential present in the tripartite division into demonstrative, dialectical, and rhetorical people; namely, that when this theoretical scheme is applied to social and political matters, individual differences of disposition and talent may harden into an essential class division.

\section{Conclusions}

Since the time of Ernest Renan's Averroès et l'Averroisme: Essai Historique (1852) many scholars have seen Ibn Rushd as a thinker whose philosophy is conversant with central tenets of the Enlightenment. They especially stress the primacy that Ibn Rushd allocates to reason, even in religious matters, his dislike of supernatural explanations, as well as his efforts to weaken the hold of the class of Islamic jurists and theologians upon philosophy, thought, and society. It is well known that Ibn Rushd had almost no following in the Islamic world but has been quite influential in shaping philosophical debates among both Jewish and Christian thinkers. This is particularly evident in 13th century France but also later in Italy where the averroists found themselves involved in notorious controversies, on the opposite side from church authorities. Thus a certain view of "Averroes" as a proto-Enlightenment figure favoring the separation of "church" and state, gradually emerged.

Despite its drawbacks, there may be a considerable amount of truth in this picture. Ibn Rushd's Aristotelian frame of mind paints a highly rationalistic picture of an eternal universe that was not created ex nihilo. His analysis of the relation of philosophy and religion in the Decisive Treatise does offer reason and philosophy prime of place in the quest for truth and does downsize the power of aggressive theologians and Islamic jurisprudents. In all of this, Ibn Rushd's spirit seems to be quite in tune with the rationalist and anticlericalist spirit of the Enlightenment. He is of course, a very serious Muslim, and a scholar deeply concerned with the revealed truth of the Qur'an and its appropriate interpretation. In this he is quite different from the philosophers of the Enlightenment whose attitude to religion ranges on the whole from clear atheism to some form of deism.

There is, however, a different dimension of Ibn Rushd's thought that needs to be addressed. His being discussed as a — broadly speaking-Enlightenment thinker is often connected to actual interest in the Muslim world today. Attention is drawn to the prioritizing of reason in Ibn Rushd's philosophy and to the support that his thinking can offer to rational discourse, secularism and, loosely speaking, intercultural communication. As such, it is seen as nurturing a beneficial antidote to the overall sorry state of numerous Islamic societies suffering from poverty, fundamentalism, authoritarian, and cleptocratic regimes, as well as from the painful historical experience of actual and mental colonization. A characteristic expression of this view was the international conference entitled "Averroes and the Enlightenment" organized in Cairo in 1994 under the auspices of the then U.N. Secretary General Boutros Boutros Gali.The book Averroës and the Enlightenment mentioned in the Introduction includes many presentations from this conference [1].

Such optimism about potentially liberating effects of Ibn Rushd's thinking may be unwarranted. The societal effects of his division of people into three distinct classes call for further elucidation.

It has already been argued that even if Ibn Rushd himself was no proponent of the Double Truth doctrine, in his treatment of issues such as that of the future life or the mode of God's knowledge, the similarity between the truth accepted by the demonstrative class and that of the masses remains elusive. What Ibn Rushd regards to be two expressions of the same truth is put into very different use 
by the people who think demonstratively as well as by the "rhetorical" ones. Such use of the belief, for example, that God knows particulars produces very different meanings for the two sets of people. One may still want to call them alternative expressions of the same belief. This, however, would hardly help shed light upon the vast differences in the ways of life and social realities that they generate and in which they are embedded.

That is, Ibn Rushd's position precludes the possibility that education may help alleviate the gap between people of different levels so that the vast majority of the common people be also given a chance to develop their abilities and think for themselves. In connection to this, Ibn Rushd's insistence that the metaphorical interpretation of the "non-obvious" Qur'anic verses not be made known to the masses is socially problematic, for it leaves the masses stuck at the level of a life largely devoid of rational reflection over a large spectrum of issues. The three-fold division of people into demonstrative, dialectical, and rhetorical is based on logical and epistemological distinctions; it can potentially, though, usher in permanent social dichotomies. We can then discern three potentially destructive societal effects of Ibn Rushd's classification of arguments and corresponding types of people.

Ibn Rushd's strictures aim at safeguarding that people of the lower class fit to a lifestyle that preserves the fundamental values of Islam. Unfortunately, it envisages this happening through the imposition of a rigid limit and denial of access to some of mankind's finest intellectual products. Ibn Rushd defends his position by pointing to the common people's poorer abilities of comprehension. In today's terms, his position would stand opposed to the generalization of higher education and to any effort to produce a more open, mentally-alert, and intellectually-energetic public. Furthermore, it facilitates the rise of a two-tier society as it draws a permanent hierarchical wedge between the main two different anthropological types (demonstrative-rhetorical) without any effort to bridge the gap and create a more integrated and enabling human community. We certainly cannot charge Ibn Rushd with being undemocratic. To do so would be anachronistic when discussing a twelfth century thinker.

Nevertheless, it has to be stressed that, according to Ibn Rushd, the demonstrative interpretation of the Scripture has to be kept from the masses in order for their faith to stay unaffected. Thus, Ibn Rushd is willing to limit rational exploration of crucial questions to a very small minority, in order to keep religious devotion intact.

Ibn Rushd's position reinforces a paradigm whereby the great majority of people are accustomed to taking things on trust, without a chance to probe a bit deeper into things. This means preventing them and, so, also preventing society from becoming mature and self-sufficient. However long and painful the process of maturity may be, to us it seems preferable to the rise of a detached and possibly arrogant elite. For how healthy is it for the majority of society to be perennially on the receptive end of the elite's decisions, edicts, and values, without much insight in to what is accepted? Unfortunately, corrupt elites presenting themselves as "modern" and enlightened have existed and enjoyed considerable power in various parts of the Islamic world. This should make us even more skeptical of Ibn Rushd's idea that a small part of the population can rationally identify with the whole of society and act on behalf of it. If the criterion of who is a member of the demonstrative class is exclusively at the hands of the demonstrative class (as it is on Ibn Rushd's analysis), there seem to be no checks and balances against the possibility of corruption in this class.

The difference between people of demonstration and rhetorical masses coincides with the distinction between unaided human rationality, on the one hand, and unreflective acceptance of 
revealed religion, on the other. Ibn Rushd does not work towards a healing of this rift within a person. A person uses either demonstrative arguments and reads the Scripture in their light, or limits oneself to rhetorical ones and does not try to reason; never both. Rather than working out an account of a synthesis between rational and rhetorical thinking and circumscribing the limits of each, Ibn Rushd keeps them apart. A serious dichotomy then makes itself felt.

From a theoretical point of view, this dichotomy raises various problems, whichever of the two alternatives is opted for. If the exclusively "demonstrative" path is taken in matters of religion, then responses like Al-Ghazālī's become possible. This means, as a philosopher, Ibn Rushd is not limited by revealed authority as he is the one to decide about how the Scripture is to be read; but there is still a problem when a philosopher uses religious concepts in a way no religious person would recognize as such. This is the point epitomizing Ibn Rushd's problem with Al-Ghazālī and it reappears in contemporary philosophical debates as well. ${ }^{9}$ If, on the contrary, one takes the purely rhetorical path, this paves the way to a whole realm where reason is absent, where religion is supposed not to need and not to seek any non-revealed ways of thinking.

Apart from the philosophical, one also has to examine the issue from a social point of view. The way in which Ibn Rushd divides people into "demonstrative" and "rhetorical" can raise serious questions here, too. They constitute separate social groups with very different mental formation and, most probably, divergent ways of living. If the "rhetorical class" should not have access to conclusions reached by demonstrative thinking and should not be encouraged to advance above the level of sensory anthropomorphic language, they are destined to make a literal understanding of the Islamic Law their exclusive guideline and compass in life. Such a literalist understanding aims at persuasion rather than a rational quest for truth (as Ibn Rushd himself is aware of).

So it habituates people to accept what they are told in revelation and does not encourage other, non-religious, ways of thinking. In actual terms, this means that for the great masses of society a non-revealed way of thinking is not part of their mental horizon. Natural reason and secular values are likely to remain quite alien to them. What is more, in such a context the divide between the secular and the religious is likely to make itself felt as a class divide. Not an enviable position for any society!

If Ibn Rushd's position is followed through, the "rhetorical class" ends up as mostly deprived of reason: but not because they are religious; the "demonstrative class," people like Ibn Rushd himself, are religious too. The "rhetorical class" find themselves on the other side of reason, in an indirect way: not in being religious as such, but in being religious in an unreflective, passive, and complacent way. This being so, the people of this class will find it very hard to think in a different way than the one based on the received authority they are accustomed too. In their case the received authority is a religious authority. For this reason the greatest part of society will not be in a position to either understand or at all relate to a secular point of view.

A delicate point needs to be made here. Islam often prides itself on being a rational religion with little taste for the supernatural. Nevertheless, when applied to the "rhetorical" class, Ibn Rushd's schema draws a considerable wedge between reason and religion since it prevents (demonstrative) reason from entering the domain of (literalist) faith. Thus, he exacerbates the opposition between reason and faith, ultimately coming - as far as the third class are concerned - to a position bordering fideism.

In the light of the three points above, we can conclude that Ibn Rushd's position on the superiority of the "people of demonstration" as opposed to the "rhetorical" ones, has critical, mostly negative

9 For a discussion of this issue, see [23]. 
effects upon society. Rather than uniting, it divides the community; rather than enabling people to develop and progress intellectually and politically, it habituates the majority to unquestioned trust of authority. Rather than enabling alternative secular values and ways of thinking, it keeps the majority within an exclusively religious paradigm and prevents society from a thoughtful appraisal of its own values. This is not very conducive to communication with other cultures, either. In the Decisive Treatise, Ibn Rushd introduces a powerful argument against literalism in religion, and Salman Rushdie is rightly impressed by it. Nevertheless, this argument is not put into the service that Rusdie would have wanted it to be. As seen in the beginning of this paper, Rushdie's aspiration was to summon Ibn Rushd's hand in order, namely, to disarm "the dead hand of literalism." For Rushdie, the latter "is what is giving power to the conservatives and the radicals." These "conservatives" and "radicals" however, are members of the class to which, according to Ibn Rushd, the non-literal(ist) interpretation must not be imparted. So even if, on a theoretical level, Ibn Rushd's philosophy pits demonstrative arguments against literal interpretation of the Qur'an and of Islamic Law, his position cannot help against "literalism" as the social reality Salman Rushdie is so eager to combat. Sadly, this is hardly an attractive position for an enlightened thinker to end up in.

\section{Conflicts of Interest}

The author declares no conflict of interest.

\section{Appendix}

Much of the analysis in this article has benefited from the following works by Ibn Rushd:

1. Averroes. Tahafut al Tahafut: The Incoherence of the Incoherence. Translated by Simon Van Den Bergh. Oxford: Gibb Memorial Trust, 2008, vol. I \& II.

2. Averroes. On Plato's Republic. Translated by Ralph Lerner. Ithaca and London: Cornell University Press, 2005.

Moreover, the two books below have been a source of stimulation and guidance:

3. Dominique Urvoy. Averroès. Les Ambitions d'un Intellectual Musulman. Paris: Flammarion, 1998.

4. Avital Wohlman. Al-Ghazali, Averroës and the Interpretation of the Qur'an: Common Sense and Philosophy in Islam. (Culture and Civilization in the Middle East Series). Translated by David Burrell. London and New York: Routledge, 2010.

\section{References}

1. Mourad Wahba, and Mona Abousenna, eds. Averroës and the Enlightenment. Amherst: Prometheus Books, 1996.

2. Anke von Kügelgen. "Averroes \& die arabische Moderne.” In Ansätze zu einer Neubegründüng des Rationalismus im Islam ("Averroes and Arabic Modernity: Attempts at a New Foundation of Rationalism in Islam.”). Leiden: Brill, 1994.

3. Stefan Wild. "Islamic Enlightenment and the Paradox of Averroes." Die Welt des Islams 36 (1996): 379-90.

4. Majid Fakhry. A History of Islamic Philosophy, 3rd ed. New York: Columbia University Press, 2004.

5. George F. Hourani. Averroes: On the Harmony of Religion and Philosophy. A translation, with introduction and notes, of Ibn Rushd's Kitab fasl al-maqal, with its appendix (Damima) and an 
extract from Kitab al-kashf 'an manahij al-adilla. London: Luzac \& Co, 1961. E. J. Gibb Memorial Series, New Series, XXI.

6. Thérèse-Anne Druart. "Philosophy in Islam." In The Cambridge Companion to Medieval Philosophy. Edited by A. S. Mcgrade. Cambridge: Cambridge University Press, 2003, pp. 97-120.

7. Catarina Belo. Averroes and Hegel on Philosophy and Religion. Farnham, Surrey and Burlington: Ashgate, 2013.

8. Ernest Renan. Averroes et L'Averroisme: Essai Historique. LaVergne: Kessinger Publishing's Legacy Reprints, 2010.

9. Nathan Gardels. "Salman Rushdie: Inside the Mind of Jihadists." Available online: http://www.huffingtonpost.com/nathan-gardels/salman-rushdie-inside-the_b_8486.html (accessed on 5 August 2015).

10. Arthur J. Arberry, ed. The Koran Interpreted: A Translation. New York: Touchstone, 1996.

11. Marmaduke Pickthall. The Meaning of the Glorious Koran. An Explanatory Translation. New York: Dorset Press, n.d.

12. Abu Hamid Muhammad al-Ghazali. The Incoherence of the Philosophers. Translated by Michael M. Marmura. Provo: Brigham Young University, 2002. (Islamic Translation Series).

13. Richard McKeon, ed. The Basic Works of Aristotle. New York: The Modern Library, 2001.

14. Dimitri Gutas. "Paul the Persian on the Classification of the Parts of Aristotle's Philosophy: A Milestone between Alexandria and Bagdad." In Greek Philosophers in the Arabic Tradition. Aldershot: Ashgate, 2000, pp. 231-67.

15. Majid Fakhry. Averroes. Ibn Rushd. His Life, Works and Influence (Great Islamic Thinkers). Oxford: Oneworld, 2001.

16. Peter Adamson, and Richard C. Taylor, eds. The Cambridge Companion to Arabic Philosophy. Cambridge: Cambridge University Press, 2005.

17. Arthur Hyman, trans. "Long Commentary on the De Anima." In Philosophy in the Middle Ages: The Christian, Islamic and Jewish Traditions. Edited by Arthur Hyman and James J. Walsh. Indianapolis: Hackett Publishing Company, 1973, pp. 324-35.

18. Norman Kretzmann, and Eleanore Stump, eds. The Cambridge Companion to Aquinas. Cambridge: Cambridge University Press, 1993.

19. Oliver Leaman. Averroes and His Philosophy. Richmond and Surrey: Curzon, 1998.

20. Charles Butterworth. "Averroës, Precursor of the Enlightenment?" Alif: Comparative Poetics 16 (1996): 6-18.

21. Oliver Leaman. A Brief Introduction to Islamic Philosophy. Cambridge: Polity Press, 1999.

22. Jonathan Barnes. "Metaphysics." In The Cambridge Companion to Aristotle. Edited by Jonathan Barnes. Cambridge: Cambridge University Press, 1995, pp. 72-77.

23. Chryssi Sidiropoulou. "Who is the God of the Qur'an? A Medieval Islamic Debate and Contemporary Philsophy of Religion." In Classic Issues in Islamic Philosophy and Theology Today (IPOP 4). Edited by Anna Theresa Tymieniecka and Nazif Muhtaroglu. Dordrecht, Heidelberg, London and New York: Springer, 2010, pp. 91-109.

(C) 2015 by the author; licensee MDPI, Basel, Switzerland. This article is an open access article distributed under the terms and conditions of the Creative Commons Attribution license (http://creativecommons.org/licenses/by/4.0/). 